\title{
Geospatial Assessment of 2012 Flood Disaster in Kogi State, Nigeria.
}

\author{
Aderoju Olaide . $\mathrm{M}^{1}$, Jantiku Jagila ${ }^{1}$, Fagbemiro Olayinka .A ${ }^{2}$, Aliyu Imrana ${ }^{1}$, \\ Nwadike Blessing . $\mathrm{K}^{1}$, Ajonye Susan $\mathrm{E}^{1}$, Salman Khalid. $\mathrm{S}^{1}$. \\ ${ }^{1 .}$ Dept of Strategic Space Application National Space Research and Development Agency. \\ 2. Dept of Mission Planning, IT \&Data Mgt. National Space Research and Development Agency.
}

\begin{abstract}
Nigeria as a nation suffers the effect of Climate Change majorly through flood events. Recent flood disasters in Nigeria have been of major concern to people, communities and institutions. Flash floods are the most common in Nigeria during the peak of the rainy season (June-October) and the 2012 flood event in Nigeria is described as the worst in recent times. Kogi State was the most affected state due to its location at the confluence of the country's major rivers (Niger-Benue Rivers). The flood events have pushed rivers to overflow their banks submerging hundreds of kilometers of the urban and rural land in Kogi State which is beyond description and has attracted humanitarian assistance from both national and international organization. In a bid to mitigate the extent of damage and casualties during a flood disaster, this study aimed at assessing, mapping and analyzing the 2012 flood disaster in Kogi state, Nigeria for an effective flood disaster risk management and proper planning. Satellites imageries [MODIS of $20^{\text {th }}$ October, 2008 (before) and $13^{\text {th }}$ October 2012 (during) and provided by NASA; Nigeria Sat-X of 2012 and SPOT 5 of 2002], Base map of Kogi State, SRTM DEM, GPS coordinates; and flood pictorial evidence acquired during field survey were integrated to map flood plain, analyse the spatial extent of inundation and disaster risk areas. It was deduced that 73 communities in 7 Local governments Area (LGA) in Kogi state which are Lokoja, Kotokarfi, Bassa, Ajaokuta, $O f u$, Idah and Ibaji were directly affected by the flood in 2012 and the estimated number of Internally Displaced Person (IDP) was about 303thousand. Also agricultural lands and farm produce were destroyed. Residence and major infrastructures like schools, health centres and transportation routes were fully inundated and destroyed making some communities inaccessible. This study showed that the natural flood plain boundary was not exceeded by the flooding, but due to high fertile land for farming activities in flood plain areas. As their major source of economic survival, the inhabitants have generated a strong affinity for these affected areas.
\end{abstract}

Keywords: Satellite data, Flood Disasters, GIS, Vulnerability, Risk, IDPs

\section{Introduction}

In recent times, it has been observed that globally that the economic cost of extreme weather and flood catastrophes is severe, and if it rises owing to climate change, it will hit poorest nations the hardest. Climate change has become a critical issue over the last few decades. The Fourth Assessment Report of the Intergovernmental Panel on Climate Change IPCC (2007) predicts that 'heavy precipitation events, which are very likely to increase in frequency, will augment flood risk'. The devastating effect of flood on the means of livelihood, particularly in the developing countries is has become more frequent and severe around the world, a situation that has been attributed to climate change and sea-level rise (Clark et al., 1998).

According to the International Federation of Red Cross and Red Crescent Societies, in 10 years from 1993 to 2002 flood disasters affected more people across the globe (140 million per year on average) than all the other natural or technological disasters put together (IFRC, 2001). Communities are vulnerable to unfamiliar hazards and can hardly cope with even the shocks leading to a constant rise in the numbers of people needing humanitarian assistance. The average number of emergencies in Africa per year has almost tripled since the mid-1980s to about 25million people in 2005 (IFRC, 2008).

According to EC (2007), a flood can be defined as a natural phenomenon that results in the temporary submerging with water of a land that does not occur under normal conditions. Floods can be predicted to a large extent, with the exception of flash floods, whose scale and nature are often less certain (ADPC, 2005). Flooding, is one of the most frequent and widespread of all environmental hazards and of various types and magnitudes, occurs in most terrestrial portions of the globe, causing huge annual losses in terms of damage and disruption to economic livelihoods, businesses, infrastructure, services and public health. Long term data on natural disasters suggest that floods and wind storms have been by far the most common causes of natural disaster worldwide over the past 100 years (Few et al. 2004). 
The effects of natural hazards such as floods can be felt at local levels, affecting communities and neighborhood, or at regional or national levels, affecting entire drainage basins and large sparse of land between states (Kwak and Kondoh, 2008).

Nigeria as a nation suffers the effect of Climate Change majorly through flood events.

In Nigeria, aside from droughts, floods cause almost 90 percent of damages resulting from natural hazards (Adeoye et al., 2009). Floods that occur in Nigeria are as a result of extensive rainfall, drainage blockages and dam failures (Jeb and Aggarwal, 2008). Flooding are common features in Nigeria during Urban flooding which occurs in towns, on flat or low-lying terrain especially where little or no provision has been made for surface drainage, or where existing drainage has been blocked with municipal waste, refuses and eroded soil sediments (Folorunsho and Awosika 2001). Flooding cannot be completely avoided, but damages from severe flooding can be reduced if effective flood prevention scheme is implemented. Mitigation is hence the cornerstone of emergency management. Flood risk' means the combination of the probability of a flood event and of the potential adverse consequences for human health, the environment, cultural heritage and economic activity associated with a flood event" (EC, 2007). Recent flood disasters in Nigeria have been of major concern to people, communities and institutions. Flash floods are the most common in Nigeria during the peak of the rainy season (June-October) and the 2012 flood event in Nigeria is described as the worst in recent times. Kogi State was the most affected state due to its location at the confluence of the country's major rivers (Niger-Benue Rivers)

Kogi state experienced a serious flood disaster in 2012 and the situation is beyond description and it has attracted humanitarian assistance from NEMA, Red Cross and many among others. It has lead most settlements inundated rendering millions of people homeless, destroyed thousands of hectares of farmlands and livestock and also loss of aquatic animals. This flooding came as a result of water release from Ladgo dam into river Benue, Shiroro and Kanji dam also released water into river Niger, as well as climate change itself which led to excess precipitation (NEMA, 2012).

In 2008, Jeb and Aggarwal stated that reduction of risk of flooding will depend largely on the amount of information on floods that is available and knowledge of the areas that are likely to be affected during a flooding event. Therefore, it is necessary to use modern day techniques in developing measures that will help government and relief agencies in identification of flood prone areas and in planning against flooding events in the future. The knowledge of remote sensing and geographical information system (GIS) is a tool which can be used to investigate and map areas that are less or more vulnerable to flooding in conjunction with forecasting techniques to predict the precipitation intensity and duration in the nearest future. Geographic Information Systems (GIS) are widely used to analyze natural hazards such as landslides, flooding, among others. GIS is extremely useful for integrating various geographic data, and for numerical analysis of such data. In this work, the use of geospatial techniques and disaster management cycle will be employed solving this devastating flood that has render people homeless and infrastructures and farmlands destroyed in Kogi state. The stated techniques above will help in the monitoring and managing subsequent flood disasters occurrence in the future.

\subsection{Statement of the Problem}

Flooding is a common event in Nigeria during rainy seasons (June - October) every year, but the 2012 flood event in Nigeria has been described as the worst in four decades. These events have made most of the country's main rivers to force their ways over their banks which made a large number of both the urban and the rural areas submerged. In Kogi State where a quite number of its citizens resides mostly in relatively low lying areas and river flood plains due to the huge natural resources and also agricultural potentials present, It has led to fast and exponential increase in human settlement and other subsistence activities in the area. Flooding has been one of the major natural disasters Kogi and environment has been experiencing from the time past but not up to the magnitude of the recently experienced flooding, during the disaster lot of lives and properties were lost, inundation of institutions, farmlands, destruction of roads, bridges and especially the major road to gain entrance from southwest into the northern area. The 2012 flood events in Kogi State have brought a devastating and unexpected hardship to the affected victims in the state, hence the use of geospatial technique for mapping and analysis for emergency management and planning is required.

\subsection{Aim}

The aim of the study is to assess, map and analyse the 2012 flood disaster in Kogi state, Nigeria for an effective flood disaster risk management.

\subsection{Objectives}

a) Identify, delineate and map out the actual flood extent of Kogi state during the 2012 flood disaster in Nigeria.

b) Map the vulnerable areas to Flooding in the study area 
c) Determine the Flood disaster impacts on the life of the people of the affected areas

d) Carry out spatial analysis of the flood plains and come up with a flood risk map of Kogi State.

e) Suggest strategies for future flood disaster and risk mitigation in the study area.

\subsection{Significance of the Study}

Kogi is one of Nigeria states that experienced a very severe flood recently which is of high magnitude and affected many local government areas, because of improper management (which includes; lack of good drainage system, blockage of drainage with refuse in the environment, absent of dams, Lack of awareness program on flood vulnerability zoning and reducing the effect of climate change caused by human activities) of flood risk over the flood plain areas which in many ways made people in the state or people close to the flood plain vulnerable.

In the past, many works have been done on assessment of flood vulnerability risk but majorities of this work do not provide a reasonable solution to this devastating disaster and also lack of proper techniques to assess the flood risk on a large spatial distribution. Although, the Federal Government is trying their best in providing a solution in terms of providing camps, foods, money many among others for the people affected by this devastating flood but planning for subsequent one is expected to be the main target, so that the state of the people's mind will be inapprehensive even after the flood. There is need for the use of Space Science and technology in solving our environmental issues in these modern days. Thus there is need for proper geospatial mapping and analysis for an effective flood disaster management and a flood contingency planning in Kogi State.

\subsection{Study Area}

Kogi state is found in the central region of Nigeria, located on the latitude $7^{\circ} 30^{\prime} \mathrm{N}$ and longitude $6^{\circ}$ $42^{\prime} \mathrm{E}$ with a total land area of $29,833 \mathrm{~km}^{2}$ and has a population of $3,595,789$ in the year 2005 which was the $24^{\text {th }}$ in the ranking of most populous state in Nigeria. It is popularly called the confluence state because of the confluence of River Niger and River Benue is at its capital. Lokoja is the first administrative capital of modernday Nigeria. The state was formed in 1991 from parts of Kwara state and Benue State. The state was as presently constituted, comprises the people of the defunct kabba province of Northern Nigeria. There are three main ethnic groups and languages in Kogi; igbala, Ebira, and Okun (Part of Yoruba) with other minorities like Bassa, a small fraction of Nupe mainly in Lokoja, Gwari, Kakanda, Owuro people( similar to Yoruba) Ogori, Mangogo and the Eggan community under Lokoja Local Government.

Kogi state is surrounded by many other states which are; Federal Capital territory (Nigeria) to the North, Nassarawa state to the Northeast, Benue state to the South, Enugun state to the Southeast, Anambra state to the south, Edo state to the Southwest, Ondo and Ekiti to the West, Niger state to the North and Kwara to the Northwest. Kogi state has 21 Local Government Areas and they are; Adavi, Ajaokuta, Ankpa, Bassa, Dekina, Ibaji, Idah, Igalamela- Odolu, Ijumu, Kabba/Bunu, Kogi, Lokoja, Mopa-Muro, Ofu, Ogori/ Mango, Okechi, Okene, Okmaboro, Omala, Yagba East, Yagba West.

The land rises from about 300 metres along the Niger-Benue conflute, to the height of between 300 and 600 metres above sea level in the uplands. Agbaja plateau, which ranges from 335 to 336 metres above sea level, and the much higher Okoroagbo hills at Ogidi in Ijumu Local Government Area are some of the predominant of land forms of the state. The state is drained by the Niger and Benue rivers and their tributaries. The confluence of the Niger and Benue rivers which could be viewed from the top of mount palti is located within the state of the river is navigable as far as Garua in the rainy season (Iloeje, 1979). The bigger rivers have wide flood plains such as the portion of the lower Niger in Kogi state, which is more than 1,600 meters wide at Lokoja, while the small streams have narrow valleys. The general rainfall is undulating and characterized by high hills, Jos plateau and numerous inselbergs and elongated ridges. The state has an annual rainfall of between $1,100 \mathrm{~mm}$ and $1,300 \mathrm{~mm}$. The rainy season last from April to October and which dry season last from November to March, is very dusty and of cold as a result of the northeasterly winds which brings in the harmattan.

Agriculture is the main concern of the economy and the principal cash crops. The Kogi people live largely in peace among themselves and their environment, they use slash and burn farming methods; each family tends to farm at varying altitudes of the sierra, producing different crops to satisfy the range of their needs, There are many farm produce from the state notably coffee, cocoa, palm oil, cashews, groundnuts, maize, cassava, yam, rice, melon and they also raise cattle on the highlands. Mineral resources include; coal, limestone, iron, petroleum and tin. The state is the home of the largest iron and steel industry in Nigeria known as Ajaokuta Steel Company Limited, one of the largest cement factories in Africa. The state by virtue of its geography, offers tourist unique experience, these attractions include natural land features, facilitating sceneries, historic monuments and relics. There are also many important tourist attractions in Kogi state which include the colonial relics (such as Lord Lugard house), the confluence of river Niger and Benue, Ogidi (an African town with formation of igneous rock mountains, traditional art and craft industry). 


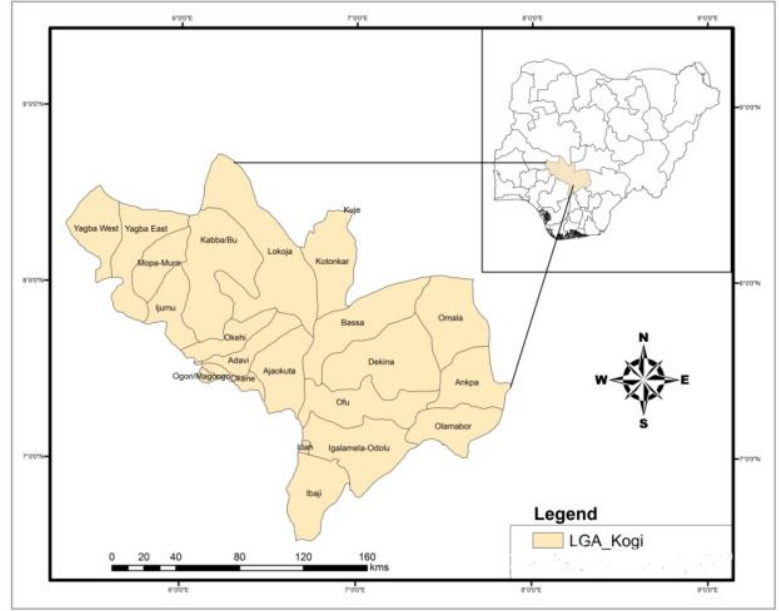

\section{Methods and Materials}

This chapter is concerned with the types of data employed in this research, the sources of the data and methods of collection, the devices used during the data collection, procedure used for the analysis (geospatial and statistical), criteria used in the analysis in order to arrive at a conclusive decision.

\subsection{Data Used} objectives. T

The Figure 1.0: Study Area Map

nmary of the datasets used in carrying out this study to achieve the set : functioned by the fact that space based techniques were to be used in the flood extent ana vuınerabinty mapping of the area.

\begin{tabular}{|l|l|l|l|}
\hline Data & Data Source & Data Source type & Year \\
\hline NigeriaSat-X (22m), & NASRDA & Secondary & 2012 \\
\hline SPOT 5 (5m) & NASRDA & Secondary & 2002 \\
\hline MODIS & NASA Website & Secondary & 2008,2012 \\
\hline SRTM DEM & GLCF & Secondary & \\
\hline $\begin{array}{l}\text { Water Body / River } \\
\text { Map }\end{array}$ & NASRDA & Secondary & 2011 \\
\hline $\begin{array}{l}\text { Kogi State Population } \\
\text { data }\end{array}$ & National Bureau of Statistics & Secondary & 2006 \\
\hline GPS coordinates & Field Work & Primary & 2012 \\
\hline Kogi State Map & NASRDA & Secondary & 2013 \\
\hline Pictures & Field Work & Primary & 2012 \\
\hline
\end{tabular}

Table 1.0: Data, Data Type and Data Sources

\subsection{Data Source and Data Acquisition}

The data used for this study were obtained from both primary and secondary sources. The primary sources involved the use of GPS receiver to obtain the coordinates of affected communities in the study area. Also, photographs were taken with a digital camera. The secondary data used are as follows; NigeriaSat-X with a resolution of $22 \mathrm{~m}$ in multispectral, SPOT 5 with $5 \mathrm{~m}$ resolution in multispectral and Water body/ River map were obtained from the National Space Research and Development Agency (NASRDA), RADARSAR and Infoterra SAR of the Niger Benue Rivers was obtained from the UN-SPIDER office of NASRDA in 2013, SRTM DEM data was also obtained from the Global Land Cover Facility (GLCF), MODIS data from NASA website, Map of Kogi State.

\subsection{Data Processing and Georeferencing.}

Area of interested state on NigeriaSat-X satellite imagery was extracted using extraction by masking from the Spatial Analyst tool of the ArcGIS 9.3 software. This was done with the aid of the Kogi state Shapefile obtained from NASRDA. The projection of the datasets was projected to WGS 1984, Universal Transverse Mercator, Datum 100 Minna, Nigeria, and Zone $32^{\circ} \mathrm{N}$. The georeferencing of the MODIS satellite images of October, 2008 and October, 2012 was done using the ArcGIS 9.3 software. The georeferencing began with the selection of four $\mathrm{X}$ and $\mathrm{Y}$ coordinates tie points that are spatially distributed and points were added, and map was then rectified. The creation of a personal geodatabase for each feature of interest was done in ArcCatalog extension of the ArcGIS 9.3. The digitizing process was done in the ArcMap environment for feature extraction. Digitizing is the process of converting geographical features from an analogue or raster map into vector format. 
Layers digitized in this project were the flood extent along the Niger Benue Rivers on the MODIS data of October of 2008 and 2012, RADARSAT, and NigeriaSat-X imageries in order to clearly see the former river extent and also the extent of the flood.

\subsection{Masking operation}

The flood plain of Kogi state was also extracted by masking from the Shuttle Radar Topographic Mission DEM data using the Spatial Analyst tool of ArcGIS 9.3 software.

\subsection{Field Work and Primary Data Collection}

A desk study was carried out before setting out for the field work to get acquainted with the terrain and to guide during the field work. A rapid map which comprised of terrain and relief maps, integrated with settlement and road maps were prepared for the flood disaster areas. The field work was carried out to validate the flood extent as captured by the satellite imageries and to identify other areas inundated by the flood. GPS receivers ((GPSmap 76 Mark (GARMIN)), Sony digital cameras, printed copies of satellite imageries and base maps were used as the field tools to delineate inundated areas. The means of transport used include boats and vehicles, which were alternated as the field situation requires. The GPS coordinates and photographs of affected communities were acquired and plotted on the maps for the emergency management and evacuation of internally displaced persons (IDPs). A survey of the affected communities in the flood disaster was carried out during the field work and basic data on the socio-economic indices such as damaged farmland/agricultural lands, number of displaced persons e.t.c. were compiled.

\subsection{Estimation of IDPs Showing the Physical Impact in Kogi State.}

The estimate of total Internally Displaced Persons (IDPs) in Kogi State was done using both the projected Kogi state population data at a growth rate of about 3\% from the 2006 census which amounted to about 3,841,884 (National Bureau of statistics, 2009), Population density of Kogi state and the flood extent area of Kogi state during the 2012 flood disaster.

\subsection{Spatial Analysis Techniques}

Spatial analysis of the inundated area carried out include query of number of affected communities and their proximity to the river channel, classification of terrain elevation into three categories of $0-100 \mathrm{~m}, 101$ $200 \mathrm{~m}, 201$ - above to represent the highly vulnerable, moderately vulnerable and safe-zone regions of the study area.

\subsubsection{Buffering}

Buffers analyses of $1000 \mathrm{~m}, 2000 \mathrm{~m}$, and $3000 \mathrm{~m}$ were carried out to validate the proximity factor in the flood disaster and risk vulnerability classes based on the physical, social, economic and environmental factors or processes of the study area.

2.6.2 Hazard zoning and Vulnerability Assessment- The zoning of areas close to the River Niger were categorized into zones (highly vulnerable, moderately vulnerable and safe-zone regions). This zoning was based on the proximity of communities to the River Niger; elevation of the terrain was also taken into consideration. These criteria were adopted from Ojigi et al., 2013.

\section{Results and Analysis}


This section presents the results of the spatial analysis carried out on the flooded communities in Kogi State and also estimates the total number of internally displaced persons in the study area.

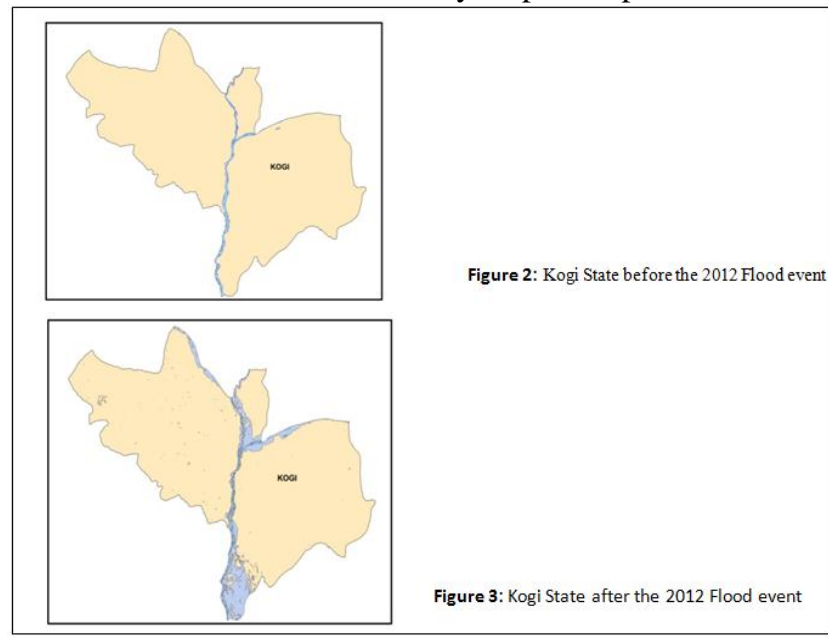

It also went further to categorize the hazard zones and also created a vulnerability and flood risk maps for study area, Kogi State.

The figure 2 and 3 respectively, showed the comparison of the spatial coverage of before and during the 2012 flood disaster event in Nigeria. It also showed Kogi state as one of the few states affected by this flooding.

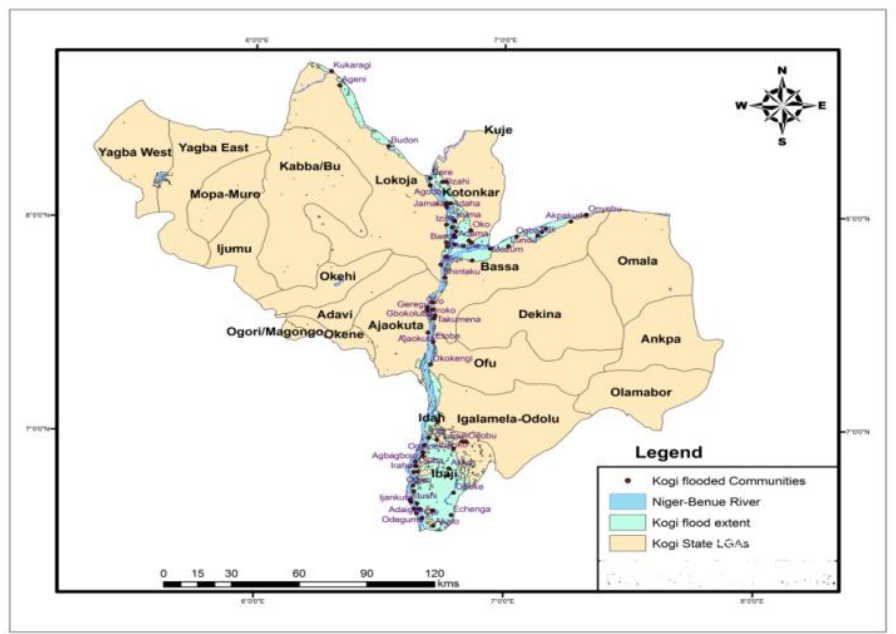

Figure 3: Kogi State after the 2012 Flood event

The figure 4.0 showed the extent of the 2012 flood event in Kogi State. It also showed that 73 communities in 7 LGA's namely Lokoja, Kotokarfi, Bassa, Ajaokuta, Ofu, Idah and Ibaji were directly affected. This occurrence was during the 2012 flooding event in which it was estimated that 345,273 people were internally displaced from their homes and large extents of agricultural farmlands were destroyed.

\subsection{Field Work Observations and Validation}

The analysis of the Ground Truthing of the 2012 Kogi flood event in combination with Digital Elevation Model (DEM) and other satellite images of the Kogi environs revealed that the natural boundary of the flood plain was not exceeded by the flood water and communities within the flood plain were fully inundated. The validation exercise also revealed that flooded water left some footprints on walls of buildings and these footprints were measured with a measuring tape and its mean were calculated to arrive at the average height of flooded water to be $12 \mathrm{~m}$ above the natural river level. The mean height of flooded water was considered because the flood height varied from one location to another even in the same communities. Another was due to the rich fertile land in flood plain areas for agricultural practices. Again, the belief of abandoning the ancestral heritage for the fear of flood was a bad idea. 


\subsection{Kogi State Flood Disaster Physical Impact in 2012}

The table 2.0 below shows the information on the projected population of Kogi state at $3 \%$ growth rate as at 2011 that was estimated to be 3,841,884 (NBS,2009). Other key information were the population density as at 2011 at 133 persons/ Square kilometers, and the total inundated area which was calculated from the map using the ArcGIS 9.3 application software. All these were put together to estimate the total number of internally displaced persons. The total number of internally displaced persons estimated during the 2012 flood disaster event was about 345,273 persons.

\begin{tabular}{|l|l|l|l|l|}
\hline $\begin{array}{l}\text { 2011 Kogi State } \\
\text { Population projection } \\
\text { @ 3\% growth rate } \\
\text { (Persons) }\end{array}$ & $\begin{array}{l}\text { Area Extent of } \\
\text { Kogi State (Sq Km) }\end{array}$ & $\begin{array}{l}\text { Population Density of } \\
\text { Kogi State ( Persons/ Sq } \\
\text { Km) }\end{array}$ & $\begin{array}{l}\text { Total Inundated } \\
\text { Area (Sq kms) }\end{array}$ & $\begin{array}{l}\text { Total Number } \\
\text { of } \\
\text { displaced } \\
\text { Internally } \\
\text { persons }\end{array}$ \\
\hline $3,841,884$ & $28,967.940$ & 133 & 2596.036 & 345,273 \\
\hline
\end{tabular}

Table 2.0: Total Inundated area and internally displaced persons during the 2012 flood in Kogi State.

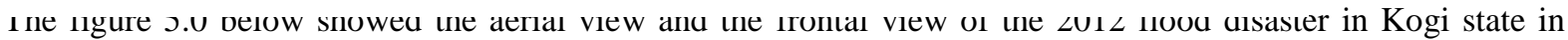
Nigeria. This showed a pictorial evidence of the physical impact of this flood disaster on human, agricultural lands and major infrastructures present in the state.
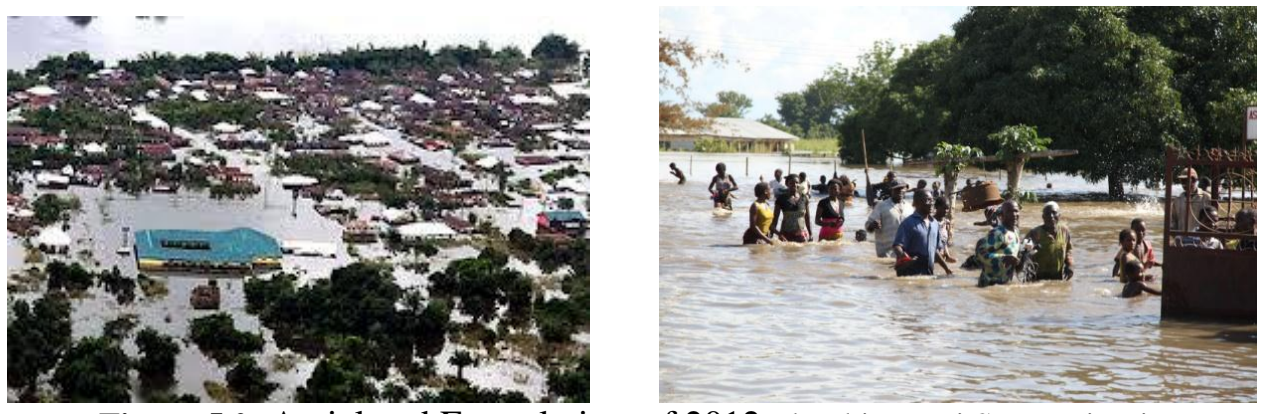

Figure 5.0: Aerial and Frontal view of 2012 Flood in Kogi State, Nigeria

\subsection{Hazard Zoning and Vulnerability Assessment}

The figures 6.0, 7.0 and 8.0 showed and explained the vulnerable areas as clearly defined in 3 hazard zones in figure 7.0. The figure 6.0 showed the Hydrology DEM of Kogi state in which the sinks were removed and all the runoff from the DEM will reach its edges. This is based on the undulating mode of the terrain with different elevations. The figure 7.0 showed the classification of the flood hazard zones in Kogi state. This classification was done in 3 categories; Highly Vulnerable, Vulnerable and Safe zone areas of the Kogi state environs. The hazard zones classification was done by a combination of both the Digital Elevation Model (DEM) and the contour value of Kogi state.

The figure 8.0 showed the vulnerable communities to flood hazard in Kogi State. This was achieved by the integration of the digital elevation model, Kogi flood extent and also the affected communities during the 2012 flood disaster event. Again from the integration of the field work, map works and modelling of the terrain, it was observed that all the 7 communities are in relatively low land areas which eventually are flood plain areas. Hence it was simply deduced from the figure 8.0 that all the 73 communities are highly vulnerable to flooding due to the hazard zoning map of figure 7.0 Furthermore all the 73 communities are at risk to flooding from the Niger-Benue Rivers.

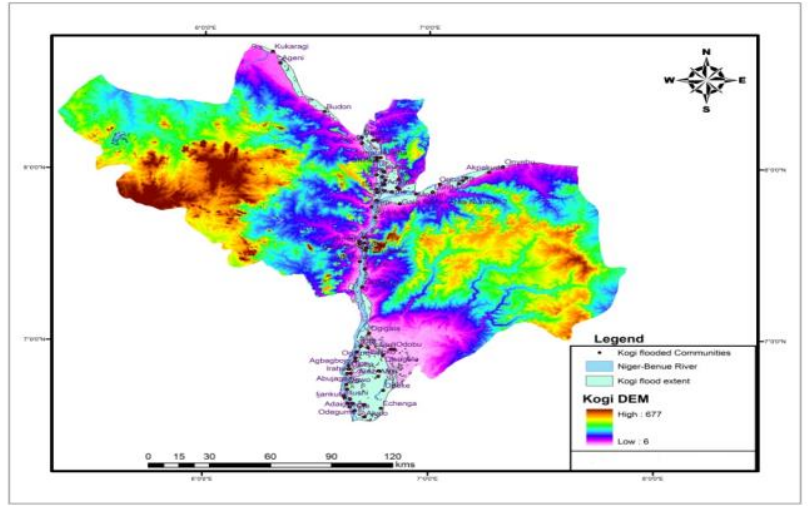

Figure 6.0: Kogi State Digital Elevation Model 


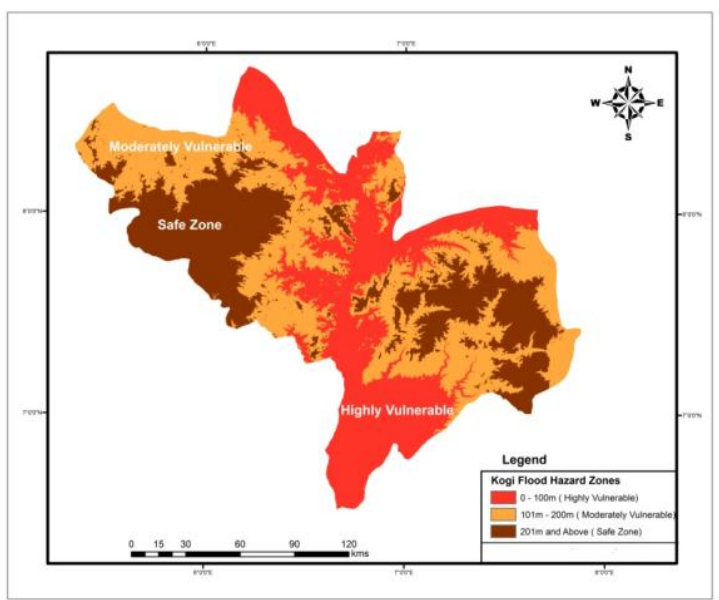

Figure 7.0: Kogi State Flood Hazard Zones

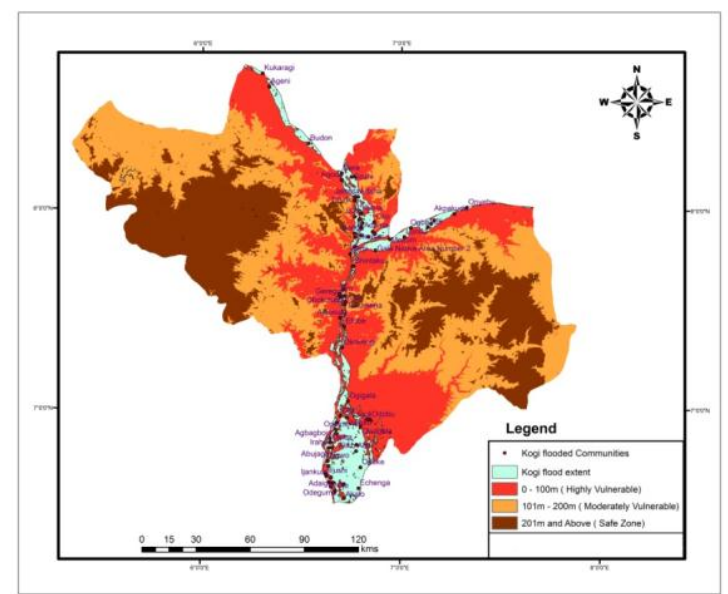

Figure 8.0: Vulnerable Communities to Flood in Kogi State.

\subsection{Terrain Analysis of Kogi State}

Understanding the terrain gives a better interpretation of the direction flowing water since water flow by gravity naturally. The Digital Elevation Model (DEM) was used where all the sinks present were filled to arrive at an agreed DEM for the creation of the flow direction grid model.

The figure 9.0 showed the flow direction grid model of Kogi state and this was created using the agreed Digital Elevation Model (DEM) of Kogi State. The flow direction grid is the output computation of the corresponding flow direction grid where values in the cells of the flow direction grid indicate the direction of the steepest descent from that cell. It also showed the variations in the slope of the study area, with values ranging from (1-37) to (211-255) which simply explains from lower to higher elevations due to the brightness valve of $0-255$. This simply implied that all the water bodies in the study area have flow paths towards the River Niger.

The flow accumulation grid of surface water in Kogi state was created using the flow direction grid model. The figure 10.0 showed the flow accumulation model in combination with the integration of the flood extent, Kogi state rivers, contour data and the flooded communities. It also showed the colour variation in the terrain from white to black which is as a result of the brightness value which simply explains that when it tends towards white the flow accumulation is greater at lower elevation while it tends towards black the flow accumulation is low at higher elevation. 


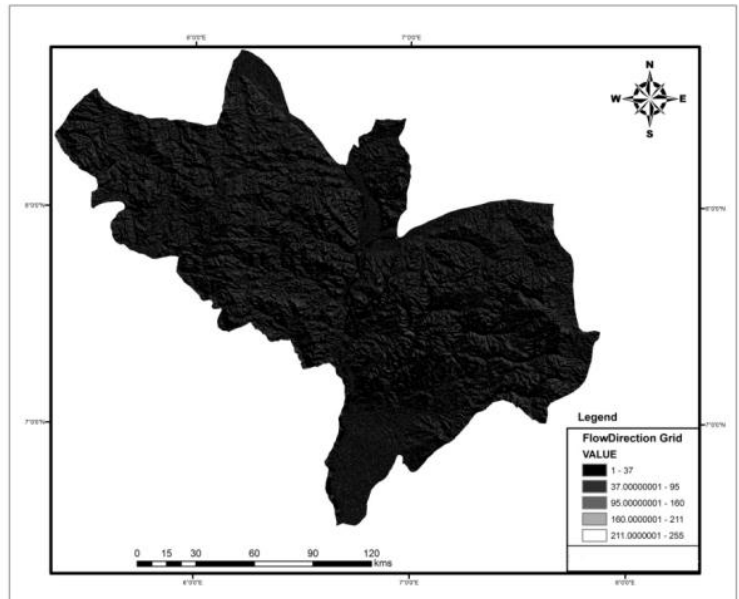

Figure 9.0: Flow Direction Grid Model of Kogi State

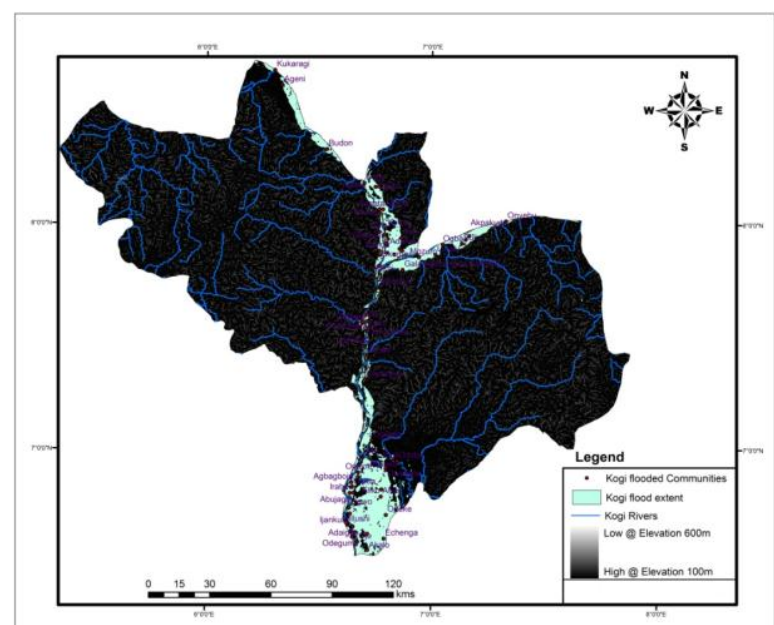

Figure 10.0: Kogi State Flow Accumulation Grid Model

\subsection{Flood Risk Map}

The need for creating a flood risk map is significant to this kind of study in order to see clearly who is at risk and the extent of the vulnerability to flood disaster. This flood risk map was done taking into consideration the elevation, the river and also a buffer distance since the farther away from the river the higher the elevation. Hence distances $1000 \mathrm{~m}, 2000 \mathrm{~m}$ and $3000 \mathrm{~m}$ were used to buffer round the rivers in Kogi state.

At buffer distances $1000 \mathrm{~m}, 2000 \mathrm{~m}$ and $3000 \mathrm{~m}$, the figure 11.0 showed that all the flooded communities fell within the 3 buffer zones except eighteen communities in four local government areas (Ibaji (Echenga, Amabo, Odeke, Alke, Aliko, Owagala, Ibaoko, Ejuli, Odobu), Bassa (Onyebu, Akpankudu, Igala native) Lokoja (Ageni, Kukaragi,Budo), and Kotokarfi (Ozahi, Rakpaku, Oko)). The field validation showed that eighteen communities were flood because they are located within the flood plains.

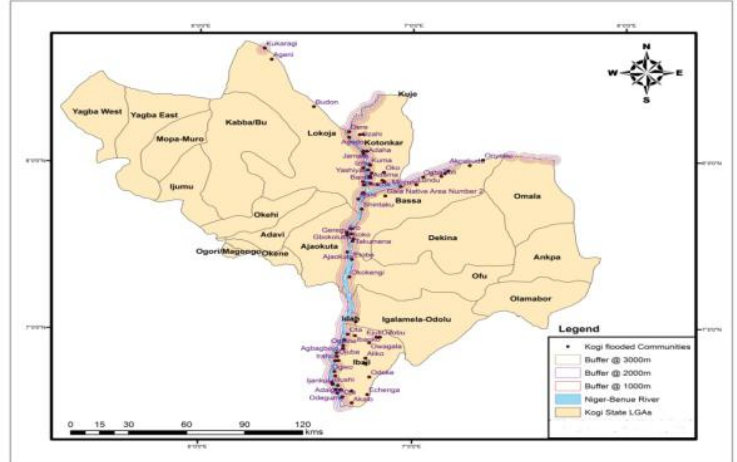

Figure 11.0: Flood Risk Map of Kogi state. 


\section{Discussion}

The figures 2.0 and 3.0 respectively, showed the comparison of the spatial coverage of before and during the flood disaster of the study area. The figure 4.0 showed affected area by the flood which was excess beyond the natural path of the River Niger, thereby inundating about 73 communities in Kogi State. Also figure 4.0 showed the extent of flood in the 2012 flood disaster in Kogi state. The estimated total number of internally displaced persons (IDPs) using both the estimated population density of Kogi state as at 2011 and total inundated area was about 345,273 persons. From figure 4.0, it was shown that 73 communities in 7 Local governments Area (LGA) of Lokoja, Kotokarfi, Bassa, Ajaokuta, Ofu, Idah and Ibaji were directly affected by the flood in 2012. The figures 6.0 and 7.0 respectively showed areas vulnerable to flood hazards and risk in Kogi State. The vulnerability were classified into three categories namely Highly Vulnerable, Vulnerable and safe zone to river flood disaster and risk using ground elevation, geology and nearness to river channel as criteria.

The figures 7.0 and 8.0 showed the areas on the terrain elevation $0-100 \mathrm{~m}$ which was classified highly vulnerable, $101-200 \mathrm{~m}$ and $201 \mathrm{~m}$ and above were classified as vulnerable and safe zone respectively. Prior to the field validation assessment, terrain analysis and flood water heights of about $12 \mathrm{~m}$ above the natural river level. It was deduced that 73 communities were inundated due to the locations on the low areas of the floods plains and the appreciable elevation for possible relief camps for evacuation is at $201 \mathrm{~m}$ and above which is regarded as the safe zone area.

The figures 9.0 and 10.0 respectively showed the direction of the flow of water and also the accumulation points of water in the study area. With the combination of terrain analysis and modelling, the figures 9.0 and 10.0 explains the possible direction of all surface water flow which is a question of the elevation of the study area because water flows due to gravity and also the accumulation points are areas of possible high risk of inundation in the study area in Kogi state. The figure 11.0 showed the flood risk map of Kogi state. And from the buffer analysis, all the areas within 3000m buffer and below are located in the flood plain areas and communities within buffers $1000 \mathrm{~m}-3000 \mathrm{~m}$ are at high risk of total loss of properties, internally displaced person and also loss of agricultural farmland and produce.

Other risk factors were poor infrastructure for evacuation and relief during the disaster, cultural and superstitious beliefs. The communities disregard the early warning issued by both NIMET and NEMA due to their ancestral norms which incurred a general loss during the 2012 flood disaster.

\subsection{Conclusion}

In this study, geospatial techniques were integrated for mapping and analysis of 2012 flood extent and vulnerable areas. The study cleared delineated the flooded areas, classified the vulnerable areas and pointing out the risk zones. It also estimated the internally displaced persons (IDPs) by the flood in Kogi state. This study generated a flood risk map for Kogi state.

\subsection{Recommendation}

Communities should be strongly discouraged from settling within the flood plains despite their ancestral, regions or cultural norms and beliefs. The construction of hydrological infrastructures like buffer dams for temporary storage of excess river flow from up-stream of a rivers, and also well constructed spill ways to avoid collapse of dams. The government should encourage maintaining a green environment and come up with policies and regulations to reduce anthropogenic activities that contributes to climate change activities.

Discouraging deforestation and promoting Afforestation, and preserving mangrove forest along the river bank as natural shield from flood disaster. Sensitization programs on flood disaster risk management and mitigation should be flogged up and promoted by governmental and non-governmental organization (NGOs) for settlements in flood plain environs and the society at large. A comprehensive mapping and the inventory of flood plain the major infrastructures in communities in the flood plain areas.

\section{References}

[1]. Adeoye, N O, Ayanlade, A and Babatimehin, O (2009), "Climate change and menace of floods in Nigerian cities: socio-economic implications", Advances in Natural and Applied Sciences, 3 (3), pages 369-377.

[2]. Asian Disaster Preparedness Center (ADPC). 2005. Disaster Risk Management in Asia, a Primer. Prepared under USAID Cooperative Agreement No. DFD-A-00-03-00077-00.

[3]. Clark G. E, Moser S.C, Ratick S.J, Mayer W.B, Emani S, Jin Weigen, Kasperson J.X, Kasperson R.E, Schwarz H.E (1998). Assessing the Vulnerability of Coastal Communities to Extreme Storms: The Case Study of Revere, MA,USA. Mitigation and Adaptation Strategies for Global Change, 3: 59-82, Kulwer Academic Publishers, Netherland.

[4]. European Commission (EC) (2007), "Directive 2007/60/EC of the European Parliament and of the Council of 23 October, 2007 on the assessment and management of flood risks", Official Journal of the European Union, L288/27-34.

[5]. Few R., Ahern M., Matthies F. and Kovats S.; Floods, health and climate change: a strategic review. Tyndall Centre for Climate Change Research, 2004, (63).

[6]. Folorunsho, R. and Awosika, L.F., 2001. Flood Mitigation in Lagos, Nigeria through Wise Management of Solid Waste: a case of Ikoyi and Victoria Islands; Nigerian, Paper presented at the UNESCO-CSI workshop, Maputo 19-23 November 2001. 
[7]. International Federation of Red Cross and Red Crescent Societies (IFRC) (2001), "Nigeria: flooding in Kano and Jigawa", Information Bulletin No 2/01 (Final), available at http://www.ifrc.org/docs/appeals/rpts01/ngfl01a2.pdf, last assessed December 25, 2013.

[8]. International Federation of Red Cross and Red Crescent Societies (IFRC) (2008), "Nigeria: floods", DREF Operation Final Report, available at http://www.ifrc.org/docs/appeals/07/MDRNG004fr_3.pdf, last assessed December 25, 2013.

[9]. Jeb, D N and Aggarwal, S P (2008), "Flood inundation hazard modeling of the River Kaduna using remote sensing and geographic information systems", Journal of Applied Sciences Research, 4 (12), pages 1822 - 1833.

[10]. Kwak, Y and Kondoh, A (2008), "A study on the extraction of multi-factor influencing floods from RS image and GIS data; a case study in Nackdong Basin, S.Korea", The International Archives Of The Photogrammetry, Remote Sensing And Spatial Information Sciences, ISPRS Congress Beijing 2008, 37, Part B8, Commission VIII, pages 421- 426.

[11]. National Bureau of Statistics (NBS) (2009), Annual Abstract of Statistics, available at www.nigerianstat.gov.ng, last assessed January 10, 2014.

[12]. National Emergency Management Agency (NEMA) (2012), Home, available at www.nema.gov.ng, last assessed December 17, 2013.

[13]. Ojigi M.L, Abdulkadir, F.I, Aderoju, M.O. (2013): Geospatial Mapping and Analysis of the 2012 flooding Disaster in central parts of Nigeria; $8^{\text {th }}$ GIS symposium, Dammaram, Saudi Arabia.

[14]. Solomon S., Qin D., Manning M., Chen Z., Marquis M., Averyt K.B., Tignor M. and Miller H.L. (Eds.), Climate Change 2007: The Physical Science Basis. Contribution of Working Group I to the Fourth Assessment Report of the Intergovernmental Panel on Climate Change. [Cambridge University Press. Cambridge, United Kingdom and New York, NY, USA, 2007] 